Horváth, Györgyi. "Towards a Methodology of the Intercultural Teaching of Hungarian Literature to Speakers of Hungarian as a Second/Foreign Language." Hungarian Cultural Studies. e-Journal of the American Hungarian Educators Association, Volume 6 (2013): http://ahea.pitt.edu DOI: 10.5195/ahea.2013.118

\title{
Towards a Methodology of the Intercultural Teaching of Hungarian Literature to Speakers of Hungarian as a Second/Foreign Language
}

\section{Györgyi Horváth}

\begin{abstract}
Although there are many Hungarian Studies scholars teaching literature to Hungarian language learners around the world, there are practically no resources available about what is happening in these classes, and what linguistic, literary and cultural challenges they pose for students and teachers. In her study, Györgyi Horváth discusses her ten-year teaching experience as a teacher of Hungarian literature to Hungarian language learners within the Hungarian Studies Program, a one-year off-site university program offered to international students, accredited by the University of Pécs, and hosted by the Balassi Institute, Budapest. She discusses the institutional and program framework she worked in, gives a detailed account of the linguistic, literary and especially the cultural competencies that were in play in these courses, and also formulates some general methodological insights about teaching Hungarian literature to language learners. Horváth concludes that teaching literature cross-culturally widens the cultural horizons of students as well as of their teachers, offering them a space for increased cultural awareness and selfreflection.
\end{abstract}

Keywords: Hungarian literature, teaching literature to language learners, language-teaching methodology, cross-cultural teaching, cultural competencies

Biography: Györgyi Horváth is a literary historian, critic, and translator of literary theory. After graduating in Linguistics \& Literature (M.A.) and Italian Studies (M.A.) from the University of Szeged, Aesthetics (M.A.) from the University of Pécs, and after the Doctoral Support Program in Gender at the Central European University, Budapest she completed a doctorate on "The Identity-Forming Function of the Historical Narrative in American Feminist Literary Criticism" at the University of Pécs in 2006. She has worked as a journalist, translator, World Literature Series editor, freelance literary critic, postdoctoral researcher, and university lecturer. Most recently she taught Gender Studies in the Department of Comparative Literature and Culture at Eötvös Loránd University, Budapest, and Hungarian literature to international students at the Balassi Institute, Budapest. She is the author of $A$ hiányzó $B$, a series of essays (Budapest: Anonymus, 2005) and Nöidö, a monograph on feminist historiography (Budapest: Kijárat, 2007). She is also co-editor of Hide and Seek. Contemporary Hungarian Writing, an Englishlanguage anthology of Hungarian literature today (Budapest: JAK, 2004), and Kortárs Irodalmi Olvasókönyv, an anthology of contemporary Hungarian literature (BBI: Budapest, 2005). Her fields of research include twentieth- and twenty-first century Hungarian literature, literary modernism, identity and literature, gender studies, and post-structuralism. 
Horváth, Györgyi. "Towards a Methodology of the Intercultural Teaching of Hungarian Literature to Speakers of Hungarian as a Second/Foreign Language." Hungarian Cultural Studies. e-Journal of the American Hungarian Educators Association, Volume 6 (2013): http://ahea.pitt.edu DOI: 10.5195/ahea.2013.118

The Hungarian Studies Program run by the Department of Hungarian Studies in the Balassi Institute (Balassi Intézet, hereafter: BI), Budapest, Hungary has a somewhat special status among institutions teaching Hungarian Studies to international university students, as it provides interdisciplinary training in Hungarian Studies to language learners where not only the language of instruction, but also the surrounding speech community is Hungarian-speaking. I taught literature there for nearly ten years (2003-2013), the longest period that any lecturer in literature has worked in the program. (The recently launched Hungarian Studies MA Program run by Eötvös Loránd (ELTE) University, Budapest has a similar profile but with a much shorter history. It is not entirely distinct from the Hungarian Studies Program in BI as there are students attending BI literature courses and getting credits for them at ELTE). This paper attempts to summarize my teaching experiences with a special focus on the institutional and program framework I had to work with. I also formulate some methodological insights about teaching Hungarian literature to language learners. Focus on the latter can be justified since there are many Hungarian Studies scholars teaching literature to Hungarian language learners around the world, yet there are almost no resources available about what actually takes place in Hungarian literature classes for language learners, and what linguistic and cultural challenges these classes pose for both students and teachers.

Furthermore, the teaching of Hungarian literature to Hungarian language learners has virtually no established methodology or suitable teaching materials. Although Hungarian Studies has some professional fora, such as a number of journals (AHEA E-journal, Hungarian Studies, Hungarológia, Hungarológiai Értesitö, and THL/THL2), and some conference papers (mostly in Hungarian), in these whenever teaching practices are at issue it is typically only language teaching that is the focus or, should a more interdisciplinary approach be employed, only general accounts of the curricula and backgrounds of particular institutions are provided. Missing from these resources in particular are observations about how to teach language learners those subdisciplines of Hungarian Studies, including literature, that go beyond language teaching. The same pattern, that is focus on language teaching, can also be observed on the general level of Hungarian Studies. (By "Hungarian Studies" here I mean "Hungarian Studies taught to nonHungarians," the sense in which the term "Hungarológia" is employed in Hungary). Although in recent decades the main figures in the field have repeatedly professed their interest in an interdisciplinary approach to Hungarian Studies as propounded by Róbert Gragger at the beginning of the twentieth century (for Gragger's significance within Hungarian Studies, see Kósa 1990; for other definitions of Hungarian Studies in the twentieth century, see Nádor 1990), little has changed. As Gábor Újváry, the former director-general of BI, stated after the Fifth International Congress of Hungarian Studies in Debrecen in 2006, "[at the congress] it seemed that many people thought that Hungarian Studies meant merely the teaching of Hungarian as a foreign language, which, in my opinion, is nonsense, since it means much more" [úgy tünt, hogy [a kongresszuson] sokan azt gondolják: a hungarológia egyenlö a magyar mint idegen nyelv oktatásával, ami szerintem képtelenség, hiszen ennél sokkal többet jelent] (Lauter et al. 2006: 131). Similarly, Zsolt K. Lengyel, Director of the Institute for Hungarian Culture in Munich, remarked that "recently [Hungarian Studies] has been increasingly downgraded to the transmission of knowledge of the Hungarian language" [az elmúlt néhány évben [a hungarológiát] egyre inkább a magyar nyelv közvetitésének a tudományává minösitették át] (Lauter et al. 2006: 133). 
Horváth, Györgyi. "Towards a Methodology of the Intercultural Teaching of Hungarian Literature to Speakers of Hungarian as a Second/Foreign Language." Hungarian Cultural Studies. e-Journal of the American Hungarian Educators Association, Volume 6 (2013): http://ahea.pitt.edu DOI: 10.5195/ahea.2013.118

Similarly, in 2012, when József Pál, former Director of the Institute for Hungarian Culture in Rome, gave a pessimistic account about the post-1989 decline of Hungarian Studies at foreign universities, he gave focus on language teaching as one of the main factors contributing to the decline. As he argued, "Building on "mere" linguistic and language teaching competencies (however high the quality of the language teaching might be) leads to a narrowing of perspectives, a drastic fall in the number of students and their isolation" [A 'csak' nyelvészeti és nyelvoktatási kompetenciák csatasorba állitása (müveljék bár a területet esetleg mégoly szinvonalasan is) beszüküléshez, a hallgatói létszám drasztikus csökkenéséhez és izolálódáshoz vezet] (Pál 2012). The general problem of putting too much emphasis on language teaching and marginalizing other sub-fields still prevails in Hungarian Studies teaching. Certainly, there are many articles on the interaction of Hungarian culture with other cultures, but typically these do not reflect on teaching practices and experiences, let alone the cross-cultural dimensions of teaching Hungarian literature to language learners. The only exception I am aware of is a very brief essay by Anna Menyhért, formerly Head of the Department of Hungarian Studies in BI, in which the author reflects on the intercultural experience and the demand for cultural selfreflection encoded in the teaching of Hungarian literature (Menyhért 2003, esp. 95-9).

The question of what exactly takes place in Hungarian literature courses for Hungarian language learners is relevant because, by sharing individual teachers' experiences, a formulation of general intercultural teaching methods and/or policies can be achieved, which can prove useful to fellow teachers of Hungarian literature irrespective of where they are active. Such a formulation could also fill an important gap, since the very limited resources on teaching Hungarian Studies currently available - if we understand the term in a broader, interdisciplinary sense, going beyond the limits of mere language teaching - tend to be very brief and abstract (see e.g. Ginter 1989, Kowalczyk 2005). At present, detailed and concrete accounts of how to teach Hungarian literature to language learners are typically passed on orally, primarily among colleagues teaching at the same venue, or at least in the same country, and these accounts usually do not develop into international conference papers or journal articles. Moreover, such reports usually employ a bicultural perspective; that is, they are limited to encounters between two cultures and no more, which may be quite understandable, since Hungarian Studies scholars typically teach in a linguistically and culturally homogeneous environment and usually have experience of only one culture as it encounters Hungarian culture. But why not develop this orally-circulated bicultural approach of Hungarian literature teaching into a scholarly, written intercultural approach? It would embrace the formulation of experiences of teaching Hungarian literature to language learners of Hungarian wherever they reside, a formulation that could in the long run also lead to an intercultural methodology of, and a transnational dialogue about, teaching Hungarian literature to language learners. The possibility of developing such an intercultural methodology is also worth considering because there already exists an established discipline of intercultural literature teaching offering useful insights for teachers of Hungarian literature. This discipline is a part of TESL/TEFL (Teaching English as a Second/Foreign Language), a field in which, from the 1990s on, the teaching of literature has received more and more scholarly attention. In the following account of my teaching experiences in BI, I will try to utilize some of these TEFL/TESL insights.

The Hungarian Studies Program in which I primarily taught was run by the Department of Hungarian Studies at BI. The BI was established on January 22, 2002, [as the successor to Nemzetközi Elökészítő Intézet (NEI)], originally serving as an umbrella organization for Hungarian Studies. Within BI the Department of Hungarian Studies, as a unit providing all 
Horváth, Györgyi. "Towards a Methodology of the Intercultural Teaching of Hungarian Literature to Speakers of Hungarian as a Second/Foreign Language." Hungarian Cultural Studies. e-Journal of the American Hungarian Educators Association, Volume 6 (2013): http://ahea.pitt.edu DOI: 10.5195/ahea.2013.118

university-level Hungarian Studies courses to international students except language teaching, enjoyed a pre-eminent position. The Department gradually lost its rank within BI in the subsequent years, mainly due to the repeated changes in the profile of the Institute which, to put it briefly, turned BI, originally an institution of higher education, into a pseudo-governmental umbrella organization of foreign cultural policy. In the course of time, BI's functions expanded significantly. BI's original mission was to incorporate in a single institution the fields of Hungarian Studies previously divided among the Institute of the Hungarian Language ("Magyar Nyelvi Intézet"), the Center for Hungarian Studies ("Hungarológiai Központ"), and the Institute for the Pre-University Preparation of International Students ("Nemzetközi Előkészítő Intézet"). At BI these three became the Department of Hungarian Language, the Department of Hungarian Studies, and the Department of Pre-University Preparation respectively. The first offered language courses in Hungarian for non-Hungarians, the second covered all university-level Hungarian Studies courses for international students (except language teaching), and the third offered pre-university preparatory courses to non-Hungarians aspiring to enter Hungarian universities, with BI as a whole serving as an institution of higher education with teaching and research as its main fields. In 2004, the Hungarian government decided to incorporate three additional organizations into BI: the Directorate of Institutes for Hungarian Culture Abroad (Külföldi Kulturális Intézetek Igazgatósága), the Áron Márton College (Márton Áron Szakkollégium, an organization for ethnic Hungarian university students coming to Hungary from the neighboring countries), and the Hungarian Scholarships Board (Magyar Ösztöndíj Bizottság, an organization coordinating the state-financed international research and visiting scholarships available to Hungarian citizens). Thus, the profile of BI changed significantly and shifted in the direction of foreign cultural diplomacy, which resulted in BI renouncing its status as an institution of higher education on January 1,2005, and with the three original departments losing their privileged status within the institutional hierarchy. In subsequent years, many other state-financed Hungarian cultural institutions and also governmental bodies were incorporated into BI. Currently under the jurisdiction of the Ministry of Public Administration and Justice, it embraces a number institutional bodies of national and foreign cultural policy, with its original mission almost lost among its new functions. As József Pál noted "It seems that at the political level, there is no one in charge of the field [i.e. of Hungarian Studies]" [Úgy tünik, politikailag nincs gazdája a területnek [ti. a hungarológiának]] (Pál 2012; for the original mission and the history of the Institute, see Pál 2012, for the work of the Department, see the general accounts of former Department Heads in Menyhért 2003, Richly 2010).

The first students specializing in Hungarian Studies arrived at BI in the academic year 2002-2003, at that time all of them enrolled in one educational program, the Hungarian Studies Program, which later divided into three distinctive branches. After January 1, 2005, when BI gave up its status as an institution of higher education, the original Hungarian Studies Program continued unmodified as a one-year, off-site university program accredited by the University of Pécs; the newly established second branch, "Hungarian Language and Hungarian-Related Studies Training Program" began to offer courses similar to those taught on the original program to speakers aged 18-35 of Hungarian as a heritage language, living in diasporas in the "Western" world (for the special features of heritage language learning, see Valdés 2001). The third branch, the "Literary Translation Program", began to offer training for future literary translators from Hungarian, aged 18-35. These two newer programs were organized as one-year, non-university tertiary education programs. The concept behind all three curricula of the Department of Hungarian Studies was the interdisciplinary approach founded by the above-mentioned 
Horváth, Györgyi. "Towards a Methodology of the Intercultural Teaching of Hungarian Literature to Speakers of Hungarian as a Second/Foreign Language." Hungarian Cultural Studies. e-Journal of the American Hungarian Educators Association, Volume 6 (2013): http://ahea.pitt.edu DOI: 10.5195/ahea.2013.118

Hungarian Studies scholar Róbert Gragger: in the morning students attended intensive language courses and in the afternoon various seminars and lectures on Hungarian Studies with literature, history, linguistics, ethnography, geography and art history as core mandatory courses and drama, gastronomy, sports history, etc. as elective courses. During my ten years in BI I taught courses in all of the programs, although primarily within the first one, which was geared to foreign learners of Hungary. Thus, this paper is based mainly on experiences gained in that program.

While interdisciplinarity was clearly a key concept in department curricula, the structure of the educational programs, and especially the composition of the groups of students (i.e. students attending the same mandatory courses) relied on a language-based concept of Hungarian Studies, which resulted in very miscellaneous student groups in the literature courses. Students would take afternoon courses not on the basis of their interest in the subject or their previous student or professional experience, but on the basis of their level of Hungarian language competency: a solution which - from the perspective of a teacher of a Hungarian Studies subject other than mere language teaching - could result in a very heterogeneous student body in the courses, a fact that was often very challenging for the teacher. Some typical examples: a Polish Hungarian Studies major who had already attended Hungarian literature courses at his home university with a fair knowledge of Western literature and a clear interest in Hungarian literature; an Italian Engineering major who did not know much about (and had little interest in) Western literature, had never read Hungarian literature in translation, but came to Hungary through an Erasmus exchange program for a semester and applied to BI because he wanted to extend his stay in the country and learn more about Hungarian culture; and, finally, a Chinese student majoring in Hungarian as a Foreign Language with a very limited background in Hungarian literature and none at all in Western literature. With such a wide disparity of backgrounds among the students, a considerable amount of time in each class was spent negotiating around their needs, competencies and interests, which varied widely from student to student and from course to course, so that ultimately the instructor could only cope by setting different professional and pedagogical goals within each course.

When I began at BI, new colleagues were not given much information about the nature of the program or how to teach (a custom that, at least in my experience, has changed little since then). There were no tried and tested textbooks, coursebooks, or other teaching materials, nor any senior colleague who might have passed on his/her experience teaching Hungarian literature to language learners. Most of us already had some experience in teaching Hungarian university students, and we were asked to give "university" seminars and lectures, but we soon realized that Balassi students rarely knew as much about Hungarian literature as, say, a better high school student in Hungary, while many of them knew much more about Western literature, culture and literary theory than their Hungarian high school peers. My general impression was that courses were similar to those of any Foreign Language and Culture Studies university program, except that our students had no first language in common, since learning groups were linguistically and culturally mixed. When I arrived at my new workplace, Anna Menyhert, then Head of the Department of Hungarian Studies, had only the following brief guidance for me: "It's like teaching at a university, although not quite the same. It's a bit like teaching at a high school, but a little different." It was this very loosely defined framework that we had to work within and fill with content in the years to come. 
Horváth, Györgyi. "Towards a Methodology of the Intercultural Teaching of Hungarian Literature to Speakers of Hungarian as a Second/Foreign Language." Hungarian Cultural Studies. e-Journal of the American Hungarian Educators Association, Volume 6 (2013): http://ahea.pitt.edu DOI: 10.5195/ahea.2013.118

Teaching literature to language learners of Hungarian is never only about conveying knowledge of literature but also encompasses helping improve their language and culture skills in the classroom. TEFL/TESL scholar Gillian Lazar, whose insights on teaching literature to speakers of English as a second language I have found extremely useful, lists a number of reasons why literature should be included in the training of language learners. Amongst her reasons, she argues that literature is very motivating, it is authentic material, it has general educational value, it is found in many syllabi, it helps students to understand another culture, it is a stimulus for language acquisition, and it develops students' interpretative abilities. Students, moreover, enjoy it. Amongst other things, literature is fun, it is highly valued and has a high status, it expands students' language awareness, and it encourages students to talk about their opinions and feelings (Lazar 2009: 14-15). These insights are often unnoticed or even resisted by people who have no experience in this kind of teaching. This happened during my Balassi years, especially in the initial period when the courses given by the Department of Hungarian Studies were as yet unfamiliar to fellow language teachers. I often had to face the fact that some of the teachers of Hungarian language, and occasionally students too (especially those with lower Hungarian language competency), thought that reading literature could "spoil" students' already acquired language skills or prove to be too difficult for language learners since they considered that literature employed a very distinctive "literary" register of the language, wholly unconnected to everyday Hungarian. Such an assumption is of course unjustified. As literary theory and TEFL/TESL studies have shown, literature does not, in fact, employ a distinctively "literary" register wholly distinct from other uses of that language, and literature courses both improve and rely on linguistic skills (see e.g. Lazar 2009: 5-8). The most evident of the skills that literature can improve is reading. Moreover, if students read authentic literary texts, they also realize they can cope with texts that at first glance seemed quite complex, which raises their general selfconfidence in reading any kind of text written in the language. Literature courses can even improve listening and conversation skills, since students are exposed to the teacher's explanations. In turn, during classroom work they improve their competency in how to express an opinion, share feelings and impressions about a text, how to express disagreement diplomatically, and so on. In short, the reading and discussion of literary texts is one of the many practices appropriate for language acquisition, and in some respects especially so, because of its ability to contribute to the improvement of a wide range of competencies.

In what follows I would like share some of my experiences about how linguistic, literary and cultural competencies are in play in the classroom in literature courses and the limitations the literature teacher often faces if the students in a given class are lacking some of these. I would like also to share how I typically addressed these issues. My aim was to provide students with Hungarian literature courses that were appropriate to their actual linguistic and cultural skills, and which significantly improved their competency in Hungarian literature, while at the same time also meeting the general standards of a university course (that is, a course that gives a general overview of canonical texts, authors, the main literary trends of a given period, their relevance and the impact they have on later work, and so forth). Because in every case the acquisition of language and culture was always the primary consideration, even in literature courses, the function of literary texts in the classroom necessarily depended on the level of the students' language skills. In the case of groups of learners preparing for the intermediate-level Hungarian language exam (group B), by the end of academic year, literature was more a means for developing the above mentioned competencies and less an aim in itself. However, in the case of groups preparing for the advanced-level language exam (group C), the focus was more on the 
Horváth, Györgyi. "Towards a Methodology of the Intercultural Teaching of Hungarian Literature to Speakers of Hungarian as a Second/Foreign Language." Hungarian Cultural Studies. e-Journal of the American Hungarian Educators Association, Volume 6 (2013): http://ahea.pitt.edu DOI: 10.5195/ahea.2013.118

improvement of competency in Hungarian literature with only occasional trouble-shooting in connection with problems arising from the absence of specific linguistic or cultural skills. More concretely, in the lower-level B groups, it was the improvement of basic linguistic skills that dominated. For example, familiarization with and active use of basic literary concepts (by that I mean such very simple things, such as the Hungarian terms for "title", "author", "poem", "text" or what is the difference in Hungarian between a "beautiful book"/"szép könyv" and a "good book"/“jó könyv"). It also provided an opportunity to review a basic list of adjectives for describing impressions of a poem or a short story, or basic formulas in expressing ideas and opinions, and also gaining some familiarity with the reading of literary texts (initially with the teacher's assistance, later more and more independently, with the help of a dictionary). Because of their dual focus on improving skills and making students "acquire a taste" for Hungarian literature, these courses were in many ways similar to straightforward language lessons. However, in higher-level B groups, students could be assigned longer texts to read and also material about Hungarian literary history. They could also be expected to take part in classroom discussions with more sophisticated views. Literature courses for the $\mathrm{C}$ groups tended to have mainly literary content, as mentioned above.

To understand a literary text, students have to possess some literary competence, that is, have some familiarity with certain literary conventions the sum of which make the individual able to construct literary meanings (see Lazar 2009: 12). In Western culture such conventions might include, for example, that short stories usually end in a resolution, or that "once a gun appears in a story it will probably go off and someone will die," or that the title usually tries to give some orientation to the reader about the content of the text and that this title-content relationship can be of many kinds (it can be, for example, ironic, tricksy, an under- or overstatement, allude to a genre or to a literary predecessor, etc). Similarly with rhyme: readers must have prior knowledge of what constitutes a rhyme in a given literature, whether rhyme is essential to a poem, what versification patterns are available in a given language, and so on. Moreover, the fact that the meaning of a text is never fixed, but is the result of a process of negotiation between the reader and the text. This is not always evident to students, especially to those from a culture in which the authority and status of literature is unquestionable. Another problem in the classroom may arise if students come from a society that is more hierarchical than the Hungarian, which can result in students not daring to come forward with ideas or opinions that differ from the teacher's, since for them the teacher is the only person in the classroom authorized to convey the meaning of literary texts. (This can be mitigated by asking students to discuss their interpretations first in mini-groups, and only afterwards sharing their conclusions with the rest of the class, including the teacher.)

Students have to possess some background cultural knowledge, too, in order to be able to recognize the outlines of a literary text and infer its implied meanings (see Lazar 2009: 9). Cultural knowledge can play a crucial part in deciphering an array of textual elements, ranging from quite easily identifiable lexical items up to less explicit, culture-bound value-systems and world-views expressed by characters, narrators, implicit readers or lyrical subjects. The most easily identifiable elements of literary texts requiring cultural background knowledge are lexical and phrasal units, especially if their reference is something that does not exist in the students' culture. Such elements can be objects, such as, for example, túrós tészta (cottage cheese pasta) or kenyércédula ("bread sticker", that is, a paper sticker on a loaf of [Hungarian] bread), customs, such as what it means "to keep to the order of dishes" [megtartani az ételek sorrendjét] at a Hungarian country wedding reception following the marriage ceremony. Sayings expressing 
Horváth, Györgyi. "Towards a Methodology of the Intercultural Teaching of Hungarian Literature to Speakers of Hungarian as a Second/Foreign Language." Hungarian Cultural Studies. e-Journal of the American Hungarian Educators Association, Volume 6 (2013): http://ahea.pitt.edu DOI: 10.5195/ahea.2013.118

certain cultural values or reflexes (such as "let the neighbor's cow die, too" [dögöljék meg a szomszéd tehene is]), beliefs and superstitions (how would you explain the figure of the "mumus", the "bogeyman", to a non-European?), folk customs and institutions, and so on. The literature teacher has to identify these elements of the text well in advance and be prepared to give explanations or glosses in order to help students with the cultural background information necessary to understand the outline of the text.

Literature conveys not only cultural content that is easy to identify in lexical or phrasal units and matches them with their real-life referent, but also value systems, world views, and culture-bound individual reactions and solutions to real-life problems. By doing so, literary texts do not mechanically document and imitate the culture and society in which they are produced, but have a more complex relationship with their environment. Commonly they refer to only one slice of it, and not merely imitatively, but rather re-structuring, re-interpreting and reworking real-life elements. While this character of literary texts seems evident to most readers, it still needs highlighting for students who are just beginning to become acquainted with another culture, especially if it is one quite distant from their own. In such cases students need a more thorough explanation of the relationship between reality and text: they need the identification of real-life elements in play in the text, an explanation of the social processes and problems reflected there, in short, a social and cultural contextualization. By that I mean such straightforward matters as, for example, the teacher highlighting the fact that "Tragedy", a short story by Zsigmond Móricz about the poverty-stricken agricultural worker János Kis trying to take revenge on his master by literally "eating him out of his wealth," does not offer a typical snapshot of Hungarian society in the 1910s, nor is the main character János Kis a typical agricultural worker of the time, nor is his solution to financial misery typical, but is rather an element of a story structured by the literary-rhetorical technique of hyperbole. While these things are evident to the educated Hungarian reader, they may be less so to someone not at home in Hungarian history and literature. Generally speaking, literature can be an excellent means of raising cultural awareness, or, as Lazar puts it, "exposing students to literature from other cultures is an enriching and exciting way of increasing their awareness of different values, beliefs, social structures and so on" (Lazar 2009: 62).

Exposing Hungarian literature to the perspectives of students with different cultural backgrounds can also have an impact on the teacher, by raising his/her awareness of the value systems and beliefs of his/her own culture. Some years ago in one of my courses, three highly canonized pieces of Hungarian literature, among other texts, featured on the reading list: a poem by Dezső Kosztolányi, A rút varangyot véresen megöltük (We Killed the Ugly Toad: It Died a Bloody Death) and two short stories, one by Péter Hajnóczy, Ki a macska? (Who is the Cat?), the other by Géza Csáth, A béka (The Frog). Coincidentally, all three texts feature detailed descriptions of characters, primarily children, torturing and killing animals, either a cat or a frog/toad. After a while my group, who came mainly from countries of former Yugoslavia, started to give me feedback that in their opinion: "Hungarian literature is full of episodes about torturing animals." I was surprised by this, since until then I had never thought of animals having any important role in these texts, let alone having the status of characters. For me, in these texts the animals exposed to human aggression were only tokens exemplifying and illustrating such human feelings as anger, anxiety, the desire to imitate others, fear and so on. However, my students' feedback gave me a fresh view of these highly canonized pieces of Hungarian literature in which until then I had only seen those "possibilities of meaning" that were both legitimated and circumscribed by the many years of institutional conditioning I had undergone during my 
Horváth, Györgyi. "Towards a Methodology of the Intercultural Teaching of Hungarian Literature to Speakers of Hungarian as a Second/Foreign Language." Hungarian Cultural Studies. e-Journal of the American Hungarian Educators Association, Volume 6 (2013): http://ahea.pitt.edu DOI: 10.5195/ahea.2013.118

education in Hungary. My students' reaction was not rooted in eco-criticism, nor in animal rights activism, nor in any major cultural difference, since they too were mainly East Europeans. The students' observations had the potential to raise my awareness of the fact that these texts, especially if read together in the same course, might convey certain assumptions about humananimal relationships and animal rights (namely that animal life does not count for much), and might be mistakenly taken to represent a general Hungarian attitude towards animals. My students were right to highlight this blind spot of mine, and provided me with an opportunity to "widen my cultural horizon" through cross-cultural literary experience (Soter 1997: 227). In turn, my role was to highlight the fact that the above body of texts is by no means representative of Hungarian literature as a whole, and torturing animals is not a constitutive element of Hungarian texts, let alone of Hungarian culture.

Even in the higher level literature courses, at least at BI, student groups were very mixed as to their literary competencies and background knowledge of Hungarian literature, a problem I usually tried to overcome by modifying course materials: tailoring reading lists to each course and distributing handouts I prepared to match the students' actual learning needs. As a teacher I had to handle the different aspirations, interests and expectations of the students toward the subject and above all to find a balance between their various learning needs: students having only a sketchy knowledge of Hungarian literature should not be burdened by too much information, while at the same time more advanced learners needed some "extra" knowledge, unavailable at their home universities, in order not to get bored. For the sake of the latter, I usually included some less canonical texts, while the courses still focused primarily on canonized texts and authors, following BI guidelines. Since, as already mentioned, there were no textbooks or course books available (only some readers hastily compiled and published in-house in 2004 and never later modified, although the teachers constantly lobbied for revised editions), handouts took over the role of reference materials and sources of background information. Such pieces of information were typically the following: some biographical data about the author (needed especially by students less interested in literature), his/her lifework, the age s/he lived in, the literary movements s/he relied on, the typical artistic techniques or styles s/he used, a brief indication of his/her importance, and occasionally also their influence on later writers or a draft outline of his/her critical reception. Individual items of literature, if studied thoroughly in class, were also contextualized as to their genre, literary antecedents, influence on later writers, and sometimes the outlines of their critical reception. The handouts aimed to provide the basic information to help students to contextualize literary texts within Hungarian literary history, including their relevance in the formation of that history. Naturally, the handouts offered more detail as the students' language skills improved. Handouts also played an important role in relieving students of the dual burden of taking extensive notes and listening to the teacher at the same time, which would have been very demanding for language learners.

The issue of literary terms emerged as another problem, since, especially at higher language levels, student groups were not at all homogenous regarding their interest in learning terminology. Some of them were quite uninterested in literature, while others used their academic year in BI to gather ideas and information for their future thesis in Hungarian Literature at their home university and so needed to learn key critical terms in order to read literary criticism in Hungarian. During my Balassi years I tried out many techniques, among which the most effective proved to be a lesson entirely dedicated to literary terms at the very beginning of the course, where I introduced and explained the most important elements of terminology, most of which were already familiar to students in their first language, and in the 
Horváth, Györgyi. "Towards a Methodology of the Intercultural Teaching of Hungarian Literature to Speakers of Hungarian as a Second/Foreign Language." Hungarian Cultural Studies. e-Journal of the American Hungarian Educators Association, Volume 6 (2013): http://ahea.pitt.edu DOI: 10.5195/ahea.2013.118

course of the semester we added only those terms that proved to be indispensable for a given topic (for further discussion on the importance of the introduction of literary terms in literature lessons, see Lazar 2009: 45, and Soter 1997: 222). This early-semester training in terminology worked well also because with the help of adequate terminology classroom debates and, as textual interpretation became more fluent, and as students were exposed to the terminology repeatedly, they soon started to use it actively. Students with more interest in literature, who were writing their term papers in Hungarian Literature, were also given personal tutorial assistance compiling their bibliographies and reading criticism. More generally they were given an introduction to Hungarian academic writing.

Although no literature course for language learners can fail to devote special attention to students' language, literary and cultural competencies, the key issue is still the selection of texts. In BI I gave both seminars and lectures, but I found that lectures worked only with very advanced learners, and therefore here I will share only my experience with seminars, not least because in lectures the reading of texts is not typical. I had to take three major factors into consideration when selecting texts: the language level of my students, the chosen text's "representativeness" of the Hungarian literary canon, and also the potential of the text to be "enjoyed" (they could not have a cultural content that was impossibly remote or complicated). In the seminars we read texts only in the original, that is, I did not use materials in simplified Hungarian for language learners, even if some of these were available. In my experience, reading authentic texts offers students a radically different experience than simplified texts: the student feels a sense of achievement in being able to read literature in Hungarian (even if initially with the teacher's assistance). As to the linguistic complexity of the texts selected, I looked for materials that were sufficiently challenging but not to the extent that students found themselves in great difficulty in understanding the text as a whole (see further Harmer on how to choose appropriate texts, Harmer 1991: 203). The linguistic limitations of the students also meant that I could not use longer texts written before the twentieth century, since they often pose a challenge even for native speakers, but we could study shorter poems written in the nineteenth century relatively easily if they were accompanied by extensive commentaries. Finally, texts written before the Language Reform of the early nineteenth century had to be excluded because students felt that the energy they had to expend on understanding them was simply not worth the effort.

I also had to be selective about which genres to teach. This was particularly troubling because it affected negatively the very genre to which most of the highly canonized texts of Hungarian literary history belong, that is to say, the novel. We could read entire novels in Hungarian only in C groups and in the higher level B groups. Higher level B groups were given extensive assistance by the teacher with their reading, and in the course of the semester students read one chapter per week from a given novel; chapters were discussed in detail in class, so that by the end of the semester students managed to read an entire novel in Hungarian, something most of them experienced for the first time in their life. The process was different with the $\mathrm{C}$ groups, where students chose a twentieth-century Hungarian novel at the beginning of the course and they read it on their own until, at the end of the semester, we dedicated an entire session to discussing their reading experience. While the $\mathrm{C}$ groups enjoyed considerable freedom in selecting a novel to be read by all group members, such freedom could not be given to the $\mathrm{B}$ groups, because there were some selection criteria that I had to keep in mind in order not to overburden students with too long or too complicated reading matter. To give an example, Dezsö Kosztolányi's novel Pacsirta (Skylark) worked well in these B groups as a semester reading because of the following features: the number of chapters was more or less the same as the 
Horváth, Györgyi. "Towards a Methodology of the Intercultural Teaching of Hungarian Literature to Speakers of Hungarian as a Second/Foreign Language." Hungarian Cultural Studies. e-Journal of the American Hungarian Educators Association, Volume 6 (2013): http://ahea.pitt.edu DOI: 10.5195/ahea.2013.118

number of weeks we met in the semester; the chapters were not too long, so students had a balanced reading load each week; it is a highly canonical novel in Hungarian literature, so it is well worth reading; and, last but not least, it has a very simple structure, a textual feature of high importance for language learners reading a novel in Hungarian for the first time. By simple structure I mean that Pacsirta is a chronologically ordered single plot novel without digressions, flashbacks or a wide array of characters, which makes it relatively easy for students to follow week after week as the story unfolds. Pacsirta was also especially suitable for reading because there is a 1963 film of this novel directed by László Ranódy and featuring such famous Hungarian actors as Klári Tolnay and Antal Páger. This offers students the chance to see how the novel is transferred to a different medium, an opportunity we always took at the end of the semester. However, when reading a novel in a foreign language for the first time, especially after having read many short texts in that language (as was usual in higher level B groups), students had repeatedly to be warned to employ new reading sub-skills, namely skimming instead of detailed reading. This was essential because while in the case of poems or short stories nearly all the elements of the text are essential for an overall understanding of the text, novels are different, and in most cases skimming is enough. Skimming lets students gain a general understanding of the text and to identify its key topics and main ideas. It also makes them aware of the fact that it is not always essential to understand every word of a novel (on the importance of developing skimming skills in second language learning, see Scrivener 1994: 152-154, Harmer 1991: 204, Riddell 2001: 102).

Apart from the special cases of reading novels mentioned above, it was the genres of poetry, short story and "short short" story that proved to be the ideal length for Hungarian language learners. (Short plays, too, could have been ideal in length, but at BI, drama courses were run separately from literature courses, by colleagues specializing in drama). Fortunately, many of the landmark texts in twentieth century Hungarian literature consist of short prose, so such canonized writers as Géza Csáth, Dezső Kosztolányi, Frigyes Karinthy, Gyula Krúdy, Zsigmond Móricz, István Örkény or Péter Hajnóczy could be easily fit into course readings. Poems, whether written in the nineteenth or the twentieth century, also worked well and even in groups at lower language skill levels, students could come up with creative and sensitive interpretations (for why poems can be read with lower level language learners, see Lazar 2009: 105). However, the reading of contemporary Hungarian prose and poetry was not without some difficulties, especially in case of authors who exploited the so-called "linguistic turn" in Hungarian literature in the 1970s, a poetics that involved a highly playful use of language with the frequent use of language games, indeterminate syntactic structures, elimination of punctuation, the fusion of various language registers and sociolects, and extensive use of intertextual allusions to literature in Hungarian and other languages. These works often pose a challenge to native Hungarians as well, so it is hardly surprising that Balassi students needed a lot of assistance to cope with their multi-layered meanings. Happily, courses on contemporary Hungarian literature were elective, so participating students were strongly motivated and interested in the subject, which also helped a lot.

I will now use "Most viszik, most viszik" (Taking Away, Taking Away), a poem written by contemporary poet Krisztina Tóth, to try to give an outline of the typical linguistic, literary and cultural problems that can emerge in a Hungarian literature seminar for language learners. The original reads as follows: 
Horváth, Györgyi. "Towards a Methodology of the Intercultural Teaching of Hungarian Literature to Speakers of Hungarian as a Second/Foreign Language." Hungarian Cultural Studies. e-Journal of the American Hungarian Educators Association, Volume 6 (2013): http://ahea.pitt.edu DOI: 10.5195/ahea.2013.118

Ne vidd el kérlek

a függönyt, amit együtt, és vidd el, kérlek, az ágyat, amin együtt, de hagyd meg, kérlek, a képet, ahol együtt, - meg a létrát, mert nem érem fel ésszel, hogy most viszik az ágyat

szuszogva viszik a kétszemélyes koporsót, és alig fér ki az ajtón. Mész utánuk karodban a fekvő ruhákkal: mintha alélt mennyasszonyt emelnél át a küszöbön.

Krisztina Tóth: "Taking Away, Taking Away"

Please don't take the curtain which we together and please do take the bed where we together and please leave behind the picture where we together -- and the ladder, because I can't get at it with my mind, that now they're taking the bed

Panting and wheezing, they carry the coffin for two, and it hardly fits through the door. You go after them, the reclining clothes in your arms: as if you were lifting the swooning bride across the threshold.

(Translated by Ottilie Mulzet) 
Horváth, Györgyi. "Towards a Methodology of the Intercultural Teaching of Hungarian Literature to Speakers of Hungarian as a Second/Foreign Language." Hungarian Cultural Studies. e-Journal of the American Hungarian Educators Association, Volume 6 (2013): http://ahea.pitt.edu DOI: 10.5195/ahea.2013.118

This poem can also be successfully read in lower level language groups, even if it contains some uncommon linguistic-rhetorical elements: first of all, the three ellipses in the first stanza (after the word "together" / "együtt" there is always a verb missing), and in the same stanza an unusual enjambement ("I can't get at it / with my mind" / "nem érem fel / ésszel") where the literal and the metaphorical senses of the same phrase are divided between the two lines. The poem is an important example of the "linguistic turn" mentioned above, in that it relativizes the meaning of individual lexical items by putting them into indeterminate syntactical structures (see the ambiguity of "I can't get at it / with my mind" / "nem érem fel / ésszel" depending on where the sentence is taken to end), and in that the rhetorical structure the poem does not follow the cognitive structure of the thoughts expressed (i.e. the poem consists of only two compound sentences as the main units of thought, but the sentences are split into 17 lines, at least in the Hungarian original, thus producing several enjambements, even across the stanzas, and such unconventional techniques as having the beginning of the second sentence in the middle of line 13, that is "az ajtón. Mész utánuk," which, unfortunately, gets lost in the English translation's "the door. / You go after them"). However, apart from these rhetorical techniques, the language of the poem is quite straightforward. Even students with lower level language skills can easily fill out the elliptical structures with the appropriate verbs, but the duality of meaning encoded in "I can't get at it / with my mind" / "nem érem fel / ésszel" (where the English translation successfully reproduces this play with the double meaning of "to get at" / "elérni, felérni" and "to get at it with my mind" / "felérni ésszel") requires highlighting and explanation on the part of the teacher. The "unliterariness" of the poem may also be a problem for students unfamiliar with contemporary poetry. The poem lacks rhyme and the lines are of varying lengths and rhythms and this too may make it alien for readers of conventional, fixed-form poetry. This problem is a matter of "literary competence," and, in my experience, if it is a problem at the very beginning of the lesson, students easily overcome it.

However, the real difficulty of understanding "Most viszik, most viszik" consists in the fact that the title invokes a literary pre-text usually unfamiliar to non-Hungarians, the Hungarian folksong "Most viszik, most viszik Danikáné lányát" (They’re taking away, taking away Mrs. Danika's daughter), originally sung as the bride is taken to the altar (or by children imitating a marriage ceremony). The poem relies heavily on the original situation of the marriage ceremony invoked by the title, using it as a frame for producing tension and contrast between marriage and the events narrated in the poem. Unless this literary pre-text of the poem is recognized, the literary meaning is altered and loses one of its important contexts. This difficulty of recognizing the folksong invoked by the title is a matter of cultural competency, and, in my experience, it is problematic even for students quite at home in Hungarian culture. While for the Hungarian reader the folksong is present as a pre-text or interpretative framework from the moment she reads the title and hence the marriage ceremony is also in play as a point of reference for the poem as whole, such connections are far from evident to the language learner. Learners of the language cannot employ a certain "double perspective" in envisioning the actions in the poem (such as the double bed turning into a double coffin, or the happy bride turning into clothes in the arms of the man moving out, or the symbolic act of lifting the bride over the threshold turning into taking the couple's bed out of the room), and so they cannot feel the striking contrast between the situation invoked by the title (marriage) and the situation narrated in the poem (separation). For language learners, even if it can be felt that separation is in the poem's focus, the memory of the happy beginnings like the marriage ceremony is not there as a point of reference, and therefore the poem's painful tone becomes much less based on happy memories or 
Horváth, Györgyi. "Towards a Methodology of the Intercultural Teaching of Hungarian Literature to Speakers of Hungarian as a Second/Foreign Language." Hungarian Cultural Studies. e-Journal of the American Hungarian Educators Association, Volume 6 (2013): http://ahea.pitt.edu DOI: 10.5195/ahea.2013.118

connected to mourning a once-happy relationship. Moreover, without the cultural background information activated by the title, the poem, if read as a love poem at all (and it is often not read as such), is nothing more than a painful description of two people separating, and the coffin, too, as a metaphor of the death of the marriage becomes incomprehensible, and it is not evident why the coffin is for two people (or why there should be a coffin at all), nor whether it should be read literally or metaphorically. In short, while emotional pain over splitting up belongings and separation from a loved one can be clearly felt, their contrast with the once happy times is not, nor is it clear that this a romantic tale (with an unhappy ending). High-level cultural competency is needed here to ensure the reader can understand that there is a romantic story hidden in the poem with its opening and closing events, and that the situation that the lyrical subject is embedded in and determined by is the situation of marriage and love, and not some other kind of human relationship ending in separation. (For students unfamiliar with Western cultures, the symbolic act of carrying the bride over the threshold can also prove mysterious, but in my experience such cases were rather exceptional.)

While there are in the poem layers of meaning that can indeed be activated by a reader coming from another culture, there are, on the other hand, layers that Hungarian readers tend to neglect precisely because of the focus on the pre-text invoked by the title. Typically I was made aware of such interpretations at the very beginning of my classes, when students shared their interpretations based on their individual prior reading of the text, when they were as yet unaware of the folksong pre-text. The students tended to place the coffin and the bride at the center of the poem, where these gained a literal sense, thus opening up the path to signifying processes in which death and mourning over the loss of a loved one played the main roles, and where other elements of the text often acquired a metaphorical sense in order to fit with the assumed general "meaning" of the poem. Here, the coffin and the bride were closely linked, and the curtain, the bed, the picture, the ladder, the door and the threshold emerged as symbolic objects with enigmatic meanings, together creating an atmosphere of a mortuary. In these interpretations that lacked knowledge of the folksong, there was also a tendency to read the bride as not merely swooning, but dead or close to death (by taking the coffin as an index of the bride's state of health), while important connections between the persons appearing in the poem, and often their identity, too, remained unclear. These included whether the figure escorting the bride and leaving the scene with her had somehow contributed to the bride's death, or whom the lyrical subject previously shared the belongings listed at the beginning of the poem with (with the bride? or with the person addressed as "you" and going away with the dead bride?), or indeed: who the lyrical subject speaking in the poem is. These uncertain points were very likely to assume metaphorical senses based on the overall "mourning" atmosphere of the poem, which is how the person escorting the bride could be interpreted as the allegorical figure of Death, taking away the memories and belongings the lyrical subject shared with the dead bride, or the equally allegorical figure of Charon, the ferryman in Greek mythology who guides the dead across the river Acheron/Styx to the underworld (based on the fact that the act of transgression is present and highlighted in the poem by the threshold), or a man in love with the bride trying to run away with her and seizing her in the very middle of a marriage ceremony, or, occasionally, Death taking Ophelia from Hamlet. The last two interpretations were less frequent since, interestingly, most of my students tended to recognize the lyrical subject speaking in the poem as a woman on the grounds that attributing so much emotional value to objects is a typically feminine way of feeling and thinking. To be sure, these interpretations, from the perspective of the Hungarian reader, are not "legitimate" or at least are "partial", since they disregard one very important pre- 
Horváth, Györgyi. "Towards a Methodology of the Intercultural Teaching of Hungarian Literature to Speakers of Hungarian as a Second/Foreign Language." Hungarian Cultural Studies. e-Journal of the American Hungarian Educators Association, Volume 6 (2013): http://ahea.pitt.edu DOI: 10.5195/ahea.2013.118

text of the poem, the folk-song. However, they are very much present in the classes, through the students, and are crucial in determining the primary impressions students develop about the poem. The teacher finds herself at the confluence of these interpretations and has to work with and upon them, negotiate with them, make them impinge upon the cultural knowledge she possesses, and also make use of them to reflect on the cultural embeddedness of her own position in the production of textual meanings. Moreover, if we acknowledge that, in case of crosscultural understanding, "it is, after all, always 'another' Hungarian culture [...] produced and reshaped by the current ongoing cross-cultural dialogue that prevails in some form" [végsö soron mindig egy, az aktuális kulturális dialógusban újrakonstituálódó [...] 'másik' magyar kultúra az, amelyik valamely alakjában érvényre jut] (Kulcsár Szabó 2000: 71-72), then why should it be natural to take it for granted that students' interpretations are "illegitimate"? Aren't Ophelia, Charon or Death somehow present in the poem as cultural-literary pre-texts? Aren't they capable of launching cross-cultural literary dialogues? Isn't it an asset to take notice of and acknowledge these interpretations, too?

\section{Works Cited}

Ginter, Károly. 1989. "A lektor hungarológiai munkája [The Work of the Language Instructor in the Field of Hungarian Studies]." In: B. Nádor Orsolya et al, eds. A hungarológia oktatás elmélete és gyakorlata. Válogatás a magyar lektori konferenciák anyagából 1969-1986. Budapest: Nemzetközi Hungarológia Központ. 26-32.

Harmer, Jeremy. 1991. The Practice of English Language Teaching. London: Longman.

Kósa, László. 1990. "A hungarológia rövid története [A Short History of Hungarian Studies]." in: Nádor 1990. 308-318.

Kowalczyk, Piotr. 2005. "Gondolatok a régi magyar irodalom oktatásáról és perspektíváiról a Jagelló Egyetem Magyar Tanszékén [Some Thoughts On the Teaching of Old Hungarian Literature and Its Prospects in the Hungarian Department of Jagiellonian University, Kraków].” THL2 1.1: 113-116.

Kulcsár Szabó, Ernő. 2000. “A (nemzeti) kultúra mint változékony üzenetek metaforája. Avagy: emlékmüve-e önmagának a 'hungarológia'? [(National) Culture as a Metaphor for Mutable Messages; or: Is Hungarian Studies a Memorial to Itself?].” Tiszatáj 54.3: 66-77.

Lauter, Éva et al. 2006. "Végeredmény vagy kiindulópont? Kerekasztal-beszélgetés a hungarológiáról [Outcome or Starting Point? Roundtable Discussion about Hungarian Studies]." Európai Utas 17.2-3: 130-141. http://www.hhrf.org/europaiutas/6364/130-141.pdf

Lazar, Gillian. 2009. Literature and Language Teaching. A Guide for Teachers and Trainers. 1993. Cambridge: Cambridge University Press.

Menyhért, Anna. 2003. "Megjegyzések a Balassi Bálint Intézet Hungarológia Oktatási Programjához [Some Notes on the Hungarian Studies Program in the Balassi Institute]." In: Gremsperger László and Nádor Orsolya, eds. A magyar mint idegen nyelv és a hungarológia oktatása az Európai Uniós csatlakozás jegyében. Konferencia a Balassi Bálint Intézetben 2003. március 13-14. Budapest: Balassi Bálint Intézet. 91-99.

Nádor, Orsolya B., ed. 1990. A hungarológia fogalma [The Notion of Hungarian Studies]. Budapest: Nemzetközi Hungarológia Központ.

Pál, József 2012. "A magyar nyelv és kultúra oktatásáról a külföldi egyetemeken [On Teaching Hungarian Language and Culture at Universities Abroad]." Magyar Tudomány 172.10: 12061216. http://www.matud.iif.hu/2012/10/03.htm 
Horváth, Györgyi. "Towards a Methodology of the Intercultural Teaching of Hungarian Literature to Speakers of Hungarian as a Second/Foreign Language." Hungarian Cultural Studies. e-Journal of the American Hungarian Educators Association, Volume 6 (2013): http://ahea.pitt.edu DOI: 10.5195/ahea.2013.118

Richly, Gábor. 2010. ”A hungarológia részképzés feladatai és lehetőségei a változó felsőoktatási környezetben [The Tasks and Possibilities of the Hungarian Studies Program in the Changing Environment of Higher Education]." THL2 6.1-2: 5-15.

Riddell, David. 2001. Teach Yourself Teaching English as a Foreign Language. London: Hodder Education.

Scrivener, Jim. 1994. Learning Teaching. London: Heinemann.

Soter, Anna O. 1997. "Reading Literature of Other Cultures. Some Issues in Critical Reception." In: Therese Rogers and Anna O. Soter, eds. Reading Across Cultures: Teaching Literature in a Diverse Society. New York: Teachers College Columbia University Press. 213-228.

Valdés, Guadalupe. 2001. "Heritage Language Students: Profiles and Possibilities." In: J. K. Peyton, D. A. Ranard, S. McGinnis, eds. Heritage Languages in America: Preserving a National Resource. Washington, DC \& McHenry, IL: Center for Applied Linguistics \& Delta Systems. 37-80. 